\title{
ECONOMIC GROWTH AND EQUALITY IN REDUCING POVERTY
}

\author{
Zaenal Muttaqin \\ The Indonesian Association of Islamic Economist \\ zaenal@gmail.com
}

\begin{abstract}
In some developing countries, the instrument to alleviate the poverty is by using the economic growth. So, the increasing in investment, infrastructure development, and macroeconomics stability always be priority from developing countries. In this article explain that economic growth is not the important factor to alleviate the poverty, because equality sometimes is more important rather than the economic growth. In this context, its measure by inequality growth trade off index (IGTI). This method is to measure the influence of economic growth to reducing the inequality, with this method every country can measure which one is better to reducing the poverty whether the economic growth or equality. With this method, Laos in 2000 show that economic growth is more important than equality, but in the same year in Thailand show that equality is more important than economic growth.
\end{abstract}

Keywords: Economic Growth; Income per Capita; Equality; Poverty

\begin{abstract}
Abstrak
Di beberapa negara berkembang, pertumbuhan ekonomi yang tinggi biasanya menjadi senjata utama dalam mengurangi kemiskinan. Oleh sebab itu, peningkatan investasi, pembangunan infrastruktur, dan stabilitas makro ekonomi selalu menjadi agenda utama negara-negara tersebut. Dalam paper ini, penulis berpendapat bahwa pertumbuhan ekonomi bukanlah faktor yang paling penting dalam mengurangi kemiskinan, sebab pemerataan seringkali lebih penting dibandingkan dengan pertumbuhan ekonomi. Dalam konteks itu, sebuah metode yang dikenal dengan Inequality Growth Trade off Index (IGTI) telah diciptakan untuk mengukur seberapa besar pertumbuhan ekonomi yang dibutuhkan untuk menutupi ketimpangan. Dengan metode itu, sebuah negara dapat mengukur apakah pertumbuhan ekonomi atau pemerataan yang lebih penting dalam mengurangi kemiskinan, tergantung kondisi masing-masing negara. Dengan metode itu, di Laos pada tahun 2000 menunjukan bahwa pertumbuhan ekonomi lebih penting dibandingkan pemerataan, namun pada tahun yang sama di Thailand menunjukkan bahwa pemerataan lebih penting dibandingkan dengan pertumbuhan ekonomi.
\end{abstract}

Kata Kunci: Pertumbuhan Ekonomi; Pendapatan per Kapita; Kesetaraan; Kemiskinan 


\section{INTRODUCTION}

The rapid elimination of poverty in all its forms is one of the incontestable objectives of development. An issue which is often recurring in discussion on poverty is whether growth is the most important strategy for poverty reduction. That issue has become subject of intense debate among scientists with the peculiarity of having trespassed academic circles to arrive at the top of the political and policy agenda. Some scientists argue that increasing growth is the most important strategy for poverty reduction, while the others see that growth is insufficient. That debate influence government policy in poverty alleviations. Some countries implement development strategy emphasizing economic growth for poverty reduction, while other countries implement development strategy which emphasizes more equality.

This paper disagree that increasing growth is the most important strategy for poverty reduction. It will argue that growth is important strategy for poverty reduction, but it is not the most important. It argues that equality is also important due to three reasons. First, market mechanism which distribute benefit of the growth often discriminate poor people. Second, key drives of economic growth are not distributed equally among the poor, so that the growth does not always benefits the poor. Third, there are huge evidences in some countries showing that inequality is detrimental to poverty reduction. Those three reason make poverty reduction cannot simply rely on increasing economic growth. Different policy needed to be taken in different situation of economic growth and inequality.

\section{GROWTH VS EQUALITY}

There is a huge debate among economists on whether growth can always reduce poverty. The proponent of the idea that growth can always reduce poverty can be traced back in the trickle-down theory that was the dominant development thinking in the 1950s and 1960s (Kakwani, 2000). The theory argue that the benefits of economic growth go to the rich first, and then in the second round the poor begin to benefit when the rich start spending their gains. As a result, the benefits of rapid economic growth rates diffuse 
automatically across all segments of society (Kakwani, et al, 2000). In recent years, an empirical research conducted by Dollar and Kraay in 137 countries shows that the income of poor raises one-for one with overall growth. According to them, average income of poor rise proportionally with average income of population (Dollar and Kraay, 2000). Similarly, a study conducted by Roemer and Gugerty found that an increase in the rate of per capita GDP growth translates into a one-for-one increase in average income of the poorest $40 \%$. GDP growth of $10 \%$ per year is associated with income growth of $10 \%$ for the poorest $40 \%$ of the population (Roemer and Gugerty, 1997).

These findings suggest that in order to reduce poverty, countries can simply focus on maximizing economic growth, avoid high inflation, and maintain macroeconomic stability, because the growth will automatically reduce poverty. However, the idea is challenged by other economists arguing that growth is not always reduces poverty, because it can also creates inequality. A classic study conducted by Kuznets in 1955-1963 found that growth increases inequality in early stages of economic development and then decrease the inequality in further stages of industrialization (Roemer and Gugerty, 1997), (Kakwani, 2000). In the early stage of economic development the growth increases inequality because the economic development is in transition period from agriculture into industrialization. At that period, people moving into industrial workplace have higher productivity and income than those who are staying in agriculture. As a result, there is income gap between people working in agriculture and those who already move to industrial workplace (Kakwani, 2000). They found that when economic growth goes up inequality increase as rate of the growth. They conclude that there appears to be little systematic relationship between growth and changes in aggregate inequality (Deininger and Squire, cited from Kakwani, 2000). In some recent study, scientists found that initial inequality is matter for poverty reduction. Economic growth in a country with high inequality has no significant effect on poverty reduction. Growth with high inequality will exacerbate poverty because they will lead to political disorder and social instability resulting in conflict violence which deepens the poverty. 


\section{GROWTH IS NOT THE MOST IMPORTANT STRATEGY}

In this paper I argue that growth is important strategy for poverty reduction, but it is not the most important factor. In fact, increasing equality is another important strategy for poverty reduction due to three reasons. First, market which distributes benefit of growth often discriminates poor people as it is shown in financial credit and externality. In the financial credit, the market can limit borrowing opportunity of poor people who have no tangible asset, because the poor cannot provide collateral for their loans. As a result, the poor cannot undertake investment project which potentially increase their income and welfares (Helpman, 2004, p.91). A good example describing this market failure is well illustrated by Dercon. Consider a village with farm households, each has different amount of land and labour. In order to produce agricultural products, they need input such as efficient technology, fertilizers and seeds. For the land-rich farmers, it is easy for them to get these the input because they can acquire credit to buy fertilizers and seeds due to availability of land for collateral. However, for poor-land farmers, it is difficult for them to provide these agricultural inputs because they cannot obtain the credit due to no enough land for collateral. At the end, only land-rich farmer can receive benefit of credit market, while the poor still have no access to the market. As a result, the land-rich farmer will become richer, while the poor-land farmers still stay in poverty. That is because the rich-land farmers can generate income from their land, but not the poor. That situation becomes worse when the failure of poor farmers to generate income make them unable to finance education and health for their family, so that they are entrapped in deeper poverty (Dercon, 2000, p. 139-140)

That situation indicates that more equal distribution benefit of growth is needed to overcome the problem. It can be done through redistributive policies such as land reform which redistribute asset of poor people as it is showed in Columbia, Brazil and South Africa (Attanasio and Binelli, 2000). Moreover, providing programmes targeting the poor could be another alternative policy to deal with the problem. Government can provide soft loan with low interest rate and without collateral, so that poor people could finance 
their profitable projects. However, such programmes should be complemented by improving capacity of micro credit institution in credit risk and cost management, so that these programmes can work efficiently.

Meanwhile, in externality the market discriminate poor because it can prevent the poor to access benefit of the growth. Externalities are said to be present if economic or other interactions create social gains or costs beyond those taken into account by those involved in the interaction. The standard example is environmental damage from production involving pollution not accounted for by the buyers and sellers of the commodity produced (Dercon, 2000). In poverty reduction, geographical location would become source of externality which hinders poor people to generate benefit of the growth. The lack of local endowment and resources often make certain areas less attractive for investment. China and India provide evidence for that situation. According to Dercon, although the countries have relatively high level of economic growth, some regions still left in poverty. In some areas, living standard of people was falling, while other areas indicate increasing in the living standard. In that situation, reducing poverty cannot rely on increasing economic growth only, because it will widen gap between people in different regions. Consequently policy which distributes benefit of the growth should be taken by the government. Massive investment programs to build up location and community capital for certain deprived areas should be endorsed. This can be done by developing infrastructures such as building roads, bridge and telecommunication for those areas as it is shown in some countries, such as Indonesia. In that country, increasing economic growth in 1970 is accomplished by a sizeable development in rural roads, communications, irrigation and ports in some deprived areas. As a result, the 14 poverty headcount in Indonesia fell from $40 \%$ to $15 \%$ in the period $1976-1990$ (Ricardo and Fuentes, 2005).

Second, the important drivers of economic growth, particularly education are not distributed equally to the poor. According to classical theory of economic growth, education is an important driver for economic growth. It can increase productivity of labour through knowledge and skill (Helpman, 2004). 
However, increasing education can increase economic growth, but it does not always reduce poverty. A study conducted by Berloffa and Segnana (2003) suggest that increasing education in some countries have different effect to economic growth and poverty. In Taiwan and Brazil, increasing education can increase economic growth and decrease poverty. However, in Mexico the education can increase economic growth but does not decrease the poverty. According to them, that happens because in Mexico schooling within population at working ages is not distributed equally, so that the education does not have positive effect to the poor people (Berloffa and Segnana 2003, p.9). That happens because unequal distribution of education to the poor people make them unable to access employment provided by economic growth due to minimum skill and inability to operate technology adopted by modern industries. As a result, it hinders poor people to receive benefit of economic growth. Moreover, in more global it can increase poverty. Low education in poor countries makes them have a relatively large supply of unskilled labour. As a result, they specialized in industries that are relatively unskilled labour intensive. In late 1970 to the mid 1990, that situation increase supply of products that were unskilled labour intensive in global market, thereby the price of the products decrease resulting in deepen poverty in least developed countries (Helpman, 2004).

Third, some evidence shows that inequality is detrimental to achievement of poverty reduction. Some countries have experienced faster rose in poverty even though their income per capita increase significantly (Cornia and Addison, 2001, p.3). In Latin America during 1985-1998 the number of the poor rose by 14 million despite a moderate rise in output per capita (Ricardo and Fuentes, 2005, p.16). In Africa the share of the poor remained broad over 1987-98. The number of the poor rose by 74 million due to persistence of high inequality. In China, sharp increase in inequality that began in the 1990s, has slowed progress on the poverty front despite continued high output of growth. Similarly, in Brazil in spite of an increase in incomes per capita, poverty stagnated over the 1980s as a result of an increase in inequality from already high levels (Cornia and Addison, 2001). 
Finally, in Bulgaria poverty increased over 1991-3 by much more than could be predicted by the average fall in per capita income, because of a sharp rise in inequality. These facts are parallel with study conducted by Ravallion and Chen (2001). The study reports that countries in which economic growth and inequality are rising have slower rate of poverty reduction than countries experiencing more equitable growth. According to them, the median rate of decline in the proportion of the population living below $\$ 1 /$ day among countries with both rising average income and rising inequality was $1.3 \%$ per year. Meanwhile, the median rate of poverty reduction was seven times higher, at about $10 \%$ per year, among the countries that combined growth in average living standards and falling inequality ( Berloffa and Segnana, 2003), (Ravallion and Chen, 2001).

\section{GROWTH AND EQUALITY ARE INTERRELATED FACTORS FOR POVERTY REDUCTION}

These four reasons suggest that reducing poverty cannot simply rely on economic growth as economic growth and inequality are interrelated factors for poverty reduction. Bourguignon argue that poverty reduction depends on income growth rate and in income distribution. Changes in poverty rate are the result of change in average income and its distribution (Bourguignon, 2003). However, the magnitude of changes in poverty reduction depends on country specific, because every country has different level of economic growth and inequality. As a result, different strategy for poverty reduction should be implemented to different countries depending on level of growth and inequality. Increasing economic growth probably would be efficient strategy for poverty reduction in low income countries with lower inequality as the growth is more important problem for the country. In contrast, reducing inequality probably would be more efficient strategy of poverty reduction for middle income countries with higher inequality, because the country more suffer serious inequality than the growth (Bourguignon, 2003).

The importance of growth and equality for poverty reduction encourage some scientist such as Kakwani to propose a method in investigating how 
much growth is required to offset the adverse effect of an increase in inequality on poverty. This trade-off between inequality and growth is quantified using a tool called the "inequality-growth trade-off index (IGTI)." This trade-off index measures how much growth in mean income or expenditure will be required to offset a 1 percent increase in inequality (Kakwani, 2000). Based on that method, Kakwani found that four countries, namely, Korea, Thailand, Lao PDR, and Philippines have different magnitude in poverty reduction, since these countries have different levels of development and inequality (Kakwani, 2000). In Thailand reduction in inequality have greater payoff for poverty reduction than promoting economic growth as the value of IGTI in that country was about 4, 04 indicating that inequality is more important problem than growth. These findings are consistent with Cornia's idea showing that a small redistribution in medium income countries such as Thailand can have large impact on the poverty reduction. In those countries, reducing inequality can achieve a reduction in poverty by $9.8 \%$, while increasing economic growth can only decrease the poverty by $1.3 \%$ (Cornia, 2000). Meanwhile, in Korea and Lao, growth maximization probably better strategy for poverty reduction because the value of IGTI for that country was around 1.23 and 0.94 , respectively.

Similarly, Ravallion propose an instrument to measure redistribution capacity of certain countries based on marginal tax rate (MTR) on rich people needed to provide revenue for the distribution (Ravallion, 2009, p.3). According to him, rich here means people living in developing countries who would not be considered poor by rich country standards (Ravallion, 2009, p.3). Based on that method, Ravallion argue that most developing countries have no capacity to implement redistribution policy because they do not full fill certain level of MTR required for the policy. As a result, increasing economic growth is needed to increase capacity of these countries to implement redistribution policies.

In addition, the idea that growth and equality are important strategy for poverty reduction stimulates the emerging of pro-poor growth strategy. Economic growth can be defined as pro-poor if it benefits the poor 
proportionally more than the non poor. Moreover, when there is a negative growth rate, growth is defined as pro-poor if the loss from growth is proportionally less for the poor than for the non poor. Under that definition, a pro-poor growth scenario will reduce poverty more rapidly than an anti poor growth scenario. Those strategies include building human capital. It can be done by refocusing public spending and progressive taxation to the poor, since in some countries particularly in Latin America public spending and taxation benefits more non-poor people than the poor (van de Walle, 1998, cited from Cornia, 2001). As a result, refocusing public spending and taxation to finance basic health care, education, and water sanitation for the poor is necessary to reduce poverty. That policy will increase living standard of the poor without hurting economic growth because it does not burden more tax on industries (Cornia, 2001). In addition, implementing agrarian reform is another pro-poor growth policy. That reform is important for poverty reduction mostly in developing countries, because poor people in that country generally live in agricultural areas. The distribution of large farms, plantation and state-run farms to the landless and to poor smallholders can improve both equality and growth, so that the policy will have significant impact on reducing poverty (Cornia, 2001). That happens because the land reform will give opportunity to poor people to generate more income from the new land they received. It also will increase productivity of agriculture because more labour will involve in agriculture production. As a result, in total well designed land reform will increase economic growth with positive impact on poverty reduction. Finally, increasing enrolment numbers in education for poor people is another propoor growth policy because the policy will equip poor people with knowledge and skill, so that they increase their productivity which enables them to access jobs and increase their incomes. The policy is important, particularly for poor people living in urban areas in which employment is provided by industries.

In some countries, those pro-poor growth policies have foster poverty reduction. In Kazakhstan and Kyrgyz Republic, the pro-poor growth policies show significant effect in poverty reduction, particularly in the 1990s (Hon, 2007). Although growth performance of these countries was not impressive as 
they were in the transition period from socialist to market economy, the patterns of growth occurred in a way that benefited the poor proportionally more than the non poor (Hon, 2007). That happens because the economic growth performance is accomplished by redistribution policies which reduce inequality. Similarly, in Uganda and Ghana the pro-poor growth particularly the redistribution of land and plantations, have big impact to poverty reduction. Although only $5 \%$ of the populations are living in agriculture, the redistribution of land and plantation can reduce the poverty by around $18.8 \%$ (Ricardo and Fuentes, 2005).

\section{CONCLUSION}

This paper argues that increasing growth is important strategy for poverty reduction, but it is not the most important. In fact, reducing inequality is another important factor for poverty reduction. That happens because market mechanism which distributes the benefit of the growth often discriminate poor people as suggested in financial credit market and externality. In financial credit market, poor people cannot access the market because they have no collateral to get the credit. As a result, they cannot finance profitable investment project which potentially increase their income. Meanwhile, externality particularly the geographical externality also prevents poor people to gain benefit of the growth. Regions in some countries cannot generate benefit of the growth as the region is not attractive for investment.

In addition, important drivers of economic growth particularly education is not distributed equally. The education can increase economic, but it does not always have positive effect on poverty reduction. That happens because unequal distribution of education make poor people cannot access employment provided by the economic growth as they have no skill and knowledge to operate technology used by modern technology. In more global context, the unequal distribution can widen inequality and exacerbate poverty as happen in mid 1970 to 1990 . At that period, the unequal distribution of education made some country have excessive unskilled labour, so that they specialized in unskilled labour intensive products. Consequently, there were 
excess supplies of unskilled labour intensive products resulting in decreasing price of the product and income of poor people.

Moreover, some evidences show that inequality is detrimental to poverty reduction. Some countries, such as Latin America, China, Bulgaria and Brazil suggest faster rose in poverty even though their income per capita increase significantly. That phenomenon is supported by some studies indicating that countries with higher equity have slower rate of poverty reduction. According to a study conducted by Berloffa and Segnana, countries with economic growth low inequality have seven time rate of poverty reduction than country with economic growth and high inequality.

Those three reasons indicate that poverty reduction cannot rely on increasing growth only because growth and equality are interrelated determinant for poverty reduction. As a result, different policy should be taken based different on level of growth and inequality. Increasing growth would be better for poverty reduction if it is implemented in poor country with low level inequality. In contrast, reducing inequality is better strategy for country with higher level of inequality than growth. Finally, the interrelated growth, inequality and poverty stimulate the emerging pro-poor growth policies. Those policies include refocusing public spending and taxation for poor people, agricultural reform and increasing schooling enrolments.

\section{REFERENCES}

Attanasio, O, 2004, 'Inequality, Growth and Redistributive Policies', paper presented to AFD-EUDN Conference 2003, Agence Française de Développement.

Bourguignon, F, 2004, 'The Poverty-Growth-Inequality Triangle, in Poverty, Inequality and Growth', paper presented to AFD-EUDN Conference 2003, Agence Française de Développement.

Berloffa and Segnana, 2003, 'On poverty, inequalities and growth: What we (don't) know', Department of economy discussion paper, JEL012, I31, I32, University of Trento, Italy. 
Dollar, D and Kraay, A, 2002, growth is good for the poor, Development Research Group discussion paper D3, 13, O1, The World Bank.

Dercon, S, 2004, The Microeconomics of Poverty and Inequality : 'The EquityEfficiency Trade-Off Revisited', paper presented to AFD-EUDN Conference 2003, Agence Française de Développement.

Cornia, G, A, and Addsion, T, 2001, 'Income distribution policies for faster poverty reduction', World Institute for Economic Development Research discussion paper, No. 2001/93, United Nation University.

Helpman, H, 2004, Mystery of economic growth, the Belknap Press, London.

Kakwani, N, et all, 2000, 'Growth, inequality and poverty, introduction', Asian Development Review, vol 18, no 2, p. 1-21.

Kakwani, N, 2000, 'Growth and Poverty reduction', Asian Development Review, vol. 18, no 2, p. 74-84.

Son, H, H, 2007, 'Interrelationship between Growth, Inequality, and Poverty: The Asian Experience', Asian Development Review, vol. 24, no. 2, p. 37-63.

Ravallion, M, 1997, 'Can high-inequality developing countries escape absolute poverty?' Economics Letters, vol. 56, p. 51-57.

Ravallion, M, 1994, 'Growth and poverty, evidence from developing countries in 1980s', Economics Letters, vol. 48, p. 411-417.

Ravallion, M, 2001, 'Growth, inequality and poverty: looking beyond averages', World Development, vol. 29, no 11, p. 1803-1815.

Ravallion, M, 2009, 'Do Poorer Countries Have Less Capacity for Redistribution?' Policy Research Working Paper, the World Bank Development Research Group.

Roemer, M and Gugerty, K,M, 1997, Does economic growth reduce poverty? Technical paper, Harvard Institute for International Development.

Ricardo and Fuentes, 2005, UNDP Human Development Report 2005: Poverty, growth and simulated poverty reduction (http://hdr.undp.org/en/reports/global/hdr2005/papers/hdr2005_fuentes_ric ardo_11.pdf) 